\title{
Profitability of Cassava Processing: A Case Study of Otukpo Lga, Benue State, Nigeria
}

\author{
Dorothy Patience Ani ${ }^{1, a^{*}}$, Hycainth Ojila ${ }^{1, b}$ and Orefi $\mathrm{Abu}^{1, \mathrm{c}}$ \\ Department of Agricultural Economics, University of Agriculture PMB 2373, Makurdi Benue State- \\ Nigeria. \\ a,*doranonye@yahoo.com, bhyojila@yahoo.com, coriefi@yahoo.com
}

\section{Keywords: Profitability, Cassava, Processing, Net margin, Benue State}

\begin{abstract}
The study investigated the economics of cassava processing in Otukpo Local Government Area, Benue State, Nigeria. Data were collected using well-structured questionnaire administered to 60 cassava processors. Data collected were analyzed using descriptive statistics, Profit function, independent sample t-test and Analysis of Variance (ANOVA). Results showed that majority of the processors were within the age group of 31-40 years with mean year of experience of 34 years. They were mostly women with an average of 8 persons per household. Traditional technologies mostly were employed by the cassava processors. The profitability analysis showed that cassava processing into garri (fried cassava granules), chips and fufu/akpu (cassava dough) are profitable, $(\mathrm{t}=23.55,11.95,12.37: \mathrm{P} \leq 0.01)$. Moreover, the result of the ANOVA showed that there was a significant difference $(\mathrm{F}=44.48: \mathrm{P} \leq 0.01)$ in the profit level of cassava processed into garri, chips and fufu/akpu. The result of the post-hoc of ANOVA shows that among the three cassava products studied, garri had the highest profit. The cassava processors encountered many set-backs like poor equipment, high cost of transportation, inadequate capital and poor road network even though processing is a viable and profitable venture. Modern processing technologies should be developed and disseminated to processors while adequate infrastructural facilities and credits should also be provided.
\end{abstract}

\section{Introduction}

Cassava (Manihot esculenta Crantz) is a crop native of South America, which was believed to have been introduced into Nigeria during the period of slave trade proliferation by the Portuguese explorers and colonizers in the sixteenth century [1]. Cassava is a drought-tolerant, perennial woody shrub and staple food crop with up to $32 \%$ (fresh) starch content which is cultivated extensively as a food crop in Africa, [2, 3]. It is one of the most important staple food crops in sub-Saharan Africa, and its average consumption exceeds $300 \mathrm{~kg}$ per person annually in some areas of Africa [4]. Cassava is a very versatile commodity with numerous uses and by-products. The leaves may be consumed as a vegetable, or cooked as a soup ingredient or dried and fed to livestock as a protein feed supplement. The stem is used for plant propagation and grafting. The roots are typically processed for human and industrial consumption. Cassava root is a good source of carbohydrates.

Cassava is processed into various products such as cassava flour (lafun), fried cassava granules (garri), cassava dough (fufu/akpu) and cassava starch [5]. It is also a source for bio-fuel as well as animal feed. Apart from livestock feeds, processed cassava serves as industrial raw material for the production of adhesives, bakery products, dextrin, dextrose glucose, lactose and sucrose. Food and beverage industries use cassava products in the production of jelly caramel and chewinggum, pharmaceutical and chemical industries also use cassava alcohol (ethanol) in cosmetic and drug production. Also, the peels are used in organo-mineral fertilizers formulation [6]. Thus, there is a very high demand for cassava products both in local and foreign markets [7]. Cassava is increasingly gaining ground as an insurance crop against hunger. Famine rarely occurs in the areas where cassava is grown since the crop provides a stable base for food production [8]: thus, it is commonly referred to as one of the major crops for food security in the tropics [9]). 
Nigeria leads the world in cassava production [10, 11]. Going by the available FAO data [12], the country's production volume for 2015 was 57.64 million metric tons, representing $37.3 \%$ of Africa's or $20.8 \%$ of the world's total production for that year [10]. The national average yield of cassava was still very low at about 13.63 metric tons per hectare reflecting a shortfall of $65.9 \%$ away from the potential yield put at about 40.0 metric tons per hectare [10]. In fact, many commercial cassava agri-businesses operate below processing capacity due to the irregular supply of fresh cassava roots [13]. Nigeria is yet to tap the full potential embedded in cassava. The country still imports some cassava products like starch, flour, sweeteners and so on, due to underutilization of available resources [14].

Cassava displays an exceptional ability to adapt to climate changes. It is tolerant to low soil fertility, resistant to drought conditions, pests and disease and suitability to store its root for long periods underground even after maturity [15]. Hence it is grown throughout the year making it preferable to the seasonal crops of yam, beans, pea, etc. Use of fertilizer is limited and it is also grown in fallow lands. The crop also grows very well on marginal soils, replacing crops that require greater soil fertility [16]. Its ability to fight hunger and poverty has made it an important commodity for intervention by the government and stakeholders in the Agricultural sector. Since most government interventions and policies are aimed at integrating the rural poor into the mainstream of the economy, one of the ways of achieving this is by adding value to their produce. The evaluation of the present state of small scale-cassava processing is therefore imperative. In order to tap the full potentials that cassava presents, there is, therefore, the need for a study on value addition to cassava and the factors that are likely to influence value addition so that rural communities whose livelihoods depend on it will benefit from the present traditional food market and new emerging markets.

Fleshly harvested cassava has a very short storage life. Processing procedures are aimed at reducing cyanide, improving storability, providing convenience and palatability [18]. Processing can increase the efficiency of land use by releasing land after harvest for other crops or for fallow to sustain soil productivity, also reduces food losses and stabilizes seasonal fluctuation in supply of the crop (Nweke, 1988). Cassava processing and marketing are agro-allied activities with substantial backward and forward linkages which can enhance income generation and employment creation capable of breaking the vicious cycle of poverty. Cassava processing is mostly done by women using traditional method which is labor-intensive and time consuming. Cassava processing was observed to be one of the ways of improving the revenue base of the rural population and meeting the demand of the urban food needs in the country. Processing of cassava provides an avenue for diversification of farming activities for farmers which has been identified as a strong panacea towards alleviating poverty from rural farming community [19].

Since profit is a major driving force in any investment; it is an indicator that will encourage or discourage participation. Profitability is the key to sustainability of agricultural innovations. Olomola [17], in analyzing the value chain of cassava, cotton, maize, rice, soybeans and sugarcane industries, placed cassava third after rice and maize based on operating profit. In terms of yield, cassava is far ahead of other crops. It is observed that cassava is a competitive commercial agricultural crop with attendant benefits to its farmers, processors, marketers and consumers.

Various initiatives on cassava are yet to yield the expected results. This may be due to the fact that they do not take account of the economic circumstances under which cassava is processed occasioned by inadequate statistics of those who engage in different cassava products particularly at the grassroots level [20]. Lawal et al. [21], in their study of the economic analysis of cassava processing in Kwara State found out that the cassava processing enterprise can be profitable. Similarly, Omolara et al. [22] in their study titled "Cost and Return Analysis of Cassava Flour (Lafun) Production among Women in Osun State, Nigeria" found that every single respondent made use of local method of processing in the study area and none of them use semi-modern and modern methods. Omotayo and Oladejo [4] worked on Profitability of Cassava-based Production Systems found that that the Gross Margin of rural farmers in Oyo state is $62,449.11 \mathrm{~K} / \mathrm{Ha}$ and profit of $54,069.57 \mathrm{~K} / \mathrm{Ha}$; implying that cassava business is a profitable venture in the study area. Thus, this 
study focused on the processing of cassava into fried cassava granules (garri), cassava dough (fufu or akpu) and cassava chips.

\section{Objectives of the Study}

The broad objective of the study was to carry out an economic analysis of cassava processing in the study area. The specific objectives were to:

i. identify the various forms of cassava products and the level of technology used in the study area;

ii. assess the costs and returns in cassava processing;

iii. compare the profitability of the various forms of processed cassava products; and

iv. identify the constraints to cassava processing.

The contribution of this research to the existing literature are three fold: first, it identified the level of technology used in cassava processing, compared the profit level of three cassava products and identified the problems of processing in the study area.

\section{Theory}

\section{Managerial Efficiency Theory of Profits}

This theory recognizes that some firms are more efficient than others in terms of management of productive operations and successfully meeting the needs of consumers. Firms with average level of efficiency earns average rate of return. Firms with higher managerial skills and production efficiency are required to be compensated by above-normal profits (i.e. economic profits). Therefore, this theory is also called compensatory theory of profits. Frank Knight argued that economic profit is a return to the entrepreneur in exchange of the risk undertaken by him (her) in the operation of a business enterprise. Because the other three factors of production (viz., land, labour and capital) have contractual agreements of payment for their services - wages, rent and interest, economic profit is a residue that may exist after these other factors have been compensated. No other factor income can be zero or negative' but profit can be, since at times there may be no profit at all or even a loss.

The compensatory theory of profits focuses on "the notion that above-normal rates of return (or economic profits) are the result of the ability of certain firms and entrepreneurs to outperform their competitors. This superior performance may stem from the fact that they are better able to satisfy current consumer demands or predict future demands."

High profits are the signal that consumers want more of the output of the industry, high profits provide the incentive for firms to expand output and for more firms to enter the industry in the long run. For a firm of above average efficiency, profits represent the reward for greater efficiency. On the other hand, lower profits or losses are the signal that consumers want less of the commodity and that production methods may not be efficient. Thus, profits provide the incentive for firms to increase their efficiency and/or produce less of the commodity, and sometimes to leave the industry for more profitable ones. It is often argued that profit arises as a result of managerial efficiency. It can be shown in many instances that management, through more efficient operations, can reduce the cost of doing business, anticipate and offset changes that will adversely affect the company's income, adopt new marketing techniques, improve product quality and expand the product line in order to increase profit.

There is hardly any doubt that business acumen regarding product development, pricing structure and marketing models can enhance profits. Yet all profits cannot be attributed to managerial efficiency. In certain instances, reasonable amount of profits exist in spite of poor management. In other cases a capable manager may be in a position where no profit can be made whatever the efficiency of his management, because of certain factors which are external to and beyond the control of his enterprise. External forces like a business recession, a sudden change in consumer taste, restrictive legislation affecting the manufacture of his product, or other unforeseen adverse external factors may depress profits and affect his true managerial skills adversely. 


\section{Materials and Methods}

\section{The Study Area}

The study area is Otukpo Local Government Area (LGA), Benue State Nigeria. Benue State is regarded as the food basket of the Nation and has 23 LGAs. Benue is located in the middle belt of Nigeria, approximately between latitudes $6^{0} 30^{\prime} \mathrm{N}$ and $8^{0} 10^{\prime} \mathrm{N}$ of the equator and longitudes $6^{0} 35^{\prime} \mathrm{E}$ and $8^{0} 10^{\prime} \mathrm{E}$ of the Greenwich meridian, at an elevation of 97 meters, above sea level in the Southern guinea savannah agro-ecological zone [23]. Otukpo town is also the traditional headquarters of Idoma land. It is strategically located at the intersection of the Eastern railway line; the only road linking the Northern parts of the country to the Eastern parts. At present, Otukpo Local Government Area is made up of four districts, namely: Otukpo, Akpa, Ugboju and Adoka. It experiences a typical tropical climate with two distinct seasons, the wet or rainy season and the dry season, annual rainfall of $150 \mathrm{~mm}$ and an average temperature which ranges between $21^{\circ} \mathrm{C}$ to $35^{\circ} \mathrm{C}$ [23]. Otukpo Local Government Area is intentionally chosen due to the fact that the production of cassava is highly predominant in the area.

Out of the four districts, Adoka was purposively chosen for this study due to predominant cassava processing in the area. Simple random sampling technique was employed to select 60 cassava processors which represent about $10 \%$ of the population. They were interviewed using well-structured questionaire. Data collected for this study were analysed using descriptive statistics, profit functions. Descriptive statistics was used to analysed socio-economic characteristics and constraints to cassava processors, profit functions were used to analyse the profitability level of cassava processing. Independent sample t-test was used to estimate the profitability of the various enterprises while Analysis of Variance (ANOVA) was used to compare the profitability levels of the different enterprises. The profit functions used were Gross margin, Net Farm Income and Rate of Returns to Investment, Operating cost ratio and Cost-Benefit Ratio. The Net farm income adopted the pattern and structure used by Ater and Umeh [24].

\section{Model Specification}

Net Income Model

$$
\mathrm{NP}=(\mathrm{TR}-\mathrm{TVC})-\mathrm{TFC}
$$

where NP - Net Income or Net Returns in Naira; TR = Total Revenue in Naira; TVC - Total Variable Cost in Naira; TFC - Total Fixed Cost in Naira = Total Amount of Depreciation on durable

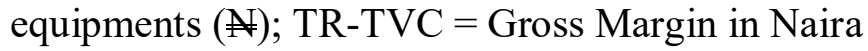

The Rates of return was calculated as:

$$
\begin{gathered}
\text { RRI=Rate of Return on Investment }=\frac{N I}{T C} X 100 \text { or } \frac{\text { Grossmargin }}{T V C} \\
\text { Operating Costs Ratio }=\frac{T V C}{T R} \\
\mathrm{~B} / \mathrm{C} \text { ratio }=\frac{\text { Total Revenue }}{\text { Total cost }} ;
\end{gathered}
$$

If $\mathrm{B} / \mathrm{C}>1=$ profitable, $\mathrm{B} / \mathrm{C}=1=$ neither profitable nor loss, and $\mathrm{B} / \mathrm{C}<1=$ not profitable

Costs were divided into two parts: fixed and variable costs. Fixed costs include depreciation of tools and equipment used, namely knife, basin, brush, grater, buckets, bamboo sieve, presser; plastic bowl, drying mats, bags, wheel barrow, headpan, The average life span for these equipments was five years and straight-line method was used. Variable costs include the cost of raw materials (cassava tubers), labor, fuel for mechanized grater, and supporting materials. Again, unpaid family labor was included in the cost component [25] which was estimated according to the predominating wage rate in the villages and the calculation of labor tasks started from peeling and did not include harvesting and transporting cassava roots from farm to the house. Valuing family labor is 
considered essential to evaluate the profitability of cassava processing in the context of cassava commercialization as economically successful business should be able to pay for all costs including realistic opportunity costs [26].

\section{Results}

\section{Forms of Cassava Processing and Technology used in Processing}

The result (Table 1) shows that majority of the respondents $(53.3 \%)$ use traditional method while only $46.7 \%$ use improved technology. The study also found that most respondents $(41.7 \%)$ process cassava into garri and fufu/akpu; $21.7 \%$ process into garri and chips while $11.7 \%$ processs cassava into garri, chips and fufu/akpu. The result further shows that none $(0 \%)$ process cassava into chips only in the study area.

Table 1: Forms of Cassava Processing and Technology Used in Processing

\begin{tabular}{llll}
\hline S/No & \multicolumn{1}{c}{ Variables } & Frequency & Percent \\
\hline $1 . \quad$ Cassava products & & \\
& Garri only & 9 & 15 \\
& Chips only & - & - \\
& Fufu/Akpu only & 1 & 1.67 \\
& Garri + chips & 13 & 21.67 \\
& Garri + Fufu/Akpu & 25 & 41.67 \\
& Chips + Fufu/Akpu & 5 & 8.33 \\
& Garri+ chips + Fufu/Akpu & 7 & 11.67 \\
2. & Method of Processing & & \\
& Traditional & 32 & 53.3 \\
& Improved & 28 & 46.7 \\
\hline
\end{tabular}

Source: Field Survey, 2016

\section{Costs and Returns in Cassava Processing}

The result of costs and returns in cassava processing is presented in Table 2 . The result shows that in processing cassava into garri, the total variable costs per $100 \mathrm{~kg}$ raw tuber was $\$ 2,574.33$ while fixed costs accounted for $27.83 \%$ of the total cost. Meanwhile, the mean price of a $100 \mathrm{~kg}$ bag of garri was $\$ 10,616$ that is $\$ 106.6 / \mathrm{kg}(\$ 28 / 100 \mathrm{~kg})$. However, the gross margin realised was N8,041.68 which suggests that it is profitable. Specifically, raw tuber accounted for $36.26 \%$ of the total variable cost, labour accounted for $18.13 \%$ while $23.05 \%$ of the total variable cost was for firewood. Bag, water and transportation accounted for $5.28 \%, 4.66 \%$ and $6.73 \%$ respectively of the total variable cost. Also, some of the processors added palm oil to their garri in order to differentiate it and add more value to their product and this amounted to $5.89 \%$ of the total variable cost. For every Naira invested, $\$ 197$ was generated as the rate of return on investment for garri was 1.976. Operating cost ratio was 0.24 meaning that the variable cost consumed $24 \%$ of sales. The benefit-cost ratio was 2.976 which depicts that cassava processing into garri is highly profitable.

In processing cassava into chips, $8.11 \%$ of the total variable cost was spent on transportation while the cost incurred on sacks accounted for $4.14 \%$ of the total variable cost. More so, the gross margin accounted for $200.28 \%$ of the total variable costs. The total variable costs of cassava chips accounted for $\$ 1,764.33$ and the net profit was $\$ 2,838.1$. The minimum and maximum gross margin calculated were $-\$ 1825$ and $\$ 13,000$; implying that while some processors incurred loses, others made high profits. Meanwhile, the mean price of chips was $\$ 5297.93 / 100 \mathrm{~kg}$ i.e. $\$ 53 / \mathrm{kg}$ $(\$ 14.32 / 100 \mathrm{~kg})$. The rate of return on investment for chips was 1.15 indicating that for every naira invested, $\$ 115$ was realized. Variable cost consumed $33 \%$ of sales. The benefit-cost ratio was 2.15 ; thus, cassava processing into chips is considered profitable and viable.

The result shows that processing cassava into fufu/akpu constitutes total variable costs of N1,688.33 from which labour and transportation accounted for $44.92 \%$ and $13.84 \%$ respectively 
and a net profit of $\$ 3,216.9$. The minimum and maximum gross margin calculated for fufu/akpu were $\$-3360$ and $\$ 26,000$; implying that while some processors incurred loses, others made high profits to the tone of $\$ 26,000$. In fufu/akpu processing, for every Naira invested, $\$ 155$ was generated $(\mathrm{RRI}=1.55)$. Again, variable cost consumed $32 \%$ of sales. The mean price of fufu/akpu was $\$ 52 / \mathrm{kg}$. However, the mean revenue was $\$ 5,293$ which represents $254.9 \%$ of the total variable costs. The enterprise is viable and profitable since the $\mathrm{BC}$ ratio was greater than 1 (2.55). A comparison of the returns to cassava processing revealed that garri had the highest gross margin which was about $197.63 \%$ of the total cost.

Table 2: Cost and Returns in Cassava processing (100kg of raw cassava tuber)

\begin{tabular}{|c|c|c|c|c|c|c|}
\hline $\mathrm{S} / \mathrm{N}$ & Variables & Mean ( & Std Devi & $\operatorname{Min}(\mathbb{N})$ & $\operatorname{Max}(\mathbb{N})$ & $\%$ of $\mathrm{TC}$ \\
\hline \multirow[t]{19}{*}{1.} & Garri & & & & & \\
\hline & Revenue & 10,616 & 5446.39 & 1,500 & 21,600 & 297.63 \\
\hline & Variable costs & & & & & \\
\hline & Cassava tubers & 933.33 & 472.06 & 0 & 2200 & 26.17 \\
\hline & Labour & 466.67 & 236.031 & 0 & 1100 & 13.08 \\
\hline & Transportation & 173.33 & 162.383 & 0 & 600 & 4.86 \\
\hline & Fire wood & 593.33 & 427.05 & 150 & 1500 & 16.63 \\
\hline & Water & 120 & 105.155 & 0 & 500 & 3.36 \\
\hline & Palm oil & 151.67 & 222.05 & 0 & 750 & 4.25 \\
\hline & Bags/sacks & 136 & 68.771 & 100 & 400 & 3.81 \\
\hline & Total Variable costs & $2,574.33$ & 1035.70 & 700 & 5370 & 72.18 \\
\hline & Fixed cost & & & & & \\
\hline & Depreciation of equ & 992.467 & 602.78 & 0 & 2500 & 27.83 \\
\hline & Total cost & $3,566.8$ & 1353.24 & 1900 & 7870 & \\
\hline & Gross Margin & 8041.6833 & 5.27934E3 & 170 & 20,250 & \\
\hline & Net profit & 7049.2167 & $5.07847 \mathrm{E} 3$ & -400 & 19,690 & \\
\hline & Rate of Return & 1.9763 & 2.00331 & -0.21 & 10.31 & \\
\hline & Operating Cost ratio & 0.24249 & 0.20965 & 0.05 & 0.93 & \\
\hline & Benefit-Cost ratio & 2.976 & 2.00331 & 0.79 & 11.31 & \\
\hline \multirow[t]{17}{*}{2.} & Chips & & & & & \\
\hline & Revenue & $5,297.93$ & 3704.98 & 0 & 14,700 & 215.38 \\
\hline & Variable costs & & & & & \\
\hline & Cassava Tubers & 645.00 & 449.561 & 0 & 1500 & 26.23 \\
\hline & Labour & 473.33 & 537.530 & 0 & 3000 & 19.25 \\
\hline & Water & 430.00 & 299.71 & 0 & 1000 & 17.48 \\
\hline & Transportation & 143.00 & 160.38 & 0 & 500 & 5.81 \\
\hline & Sacks & 73.00 & 69.98 & 0 & 200 & 2.97 \\
\hline & Total Variable costs & 1764.33 & 1129.37 & 0 & 4750 & 71.73 \\
\hline & Fixed cost & & & & & \\
\hline & Depreciation of equ & 695.50 & 653.48 & 0 & 2300 & 28.28 \\
\hline & Total cost & 2459.8 & 1571.54 & 0 & 6100 & \\
\hline & Gross Margin & 3533.6 & 3096.63 & -1825 & 13000 & \\
\hline & Net profit & 2838.1 & 2719.27 & -2075 & 11800 & \\
\hline & Rate of Return & 1.1537 & 1.196 & -1.00 & 5.40 & \\
\hline & Operating Cost ratio & 0.333 & 0.230 & 0 & 0.88 & \\
\hline & Benefit-Cost ratio & 2.1538 & 1.36059 & 0 & 6.40 & \\
\hline \multirow[t]{5}{*}{3.} & Fufu/Akpu & & & & & \\
\hline & Revenue & $5,293.0$ & $6,346.46$ & 0 & 19,000 & 254.9 \\
\hline & Variable costs & & & & & \\
\hline & Cassava tubers & 316.00 & 273.85 & 0 & 800 & 15.22 \\
\hline & Labour & 758.33 & 599.59 & 0 & 1800 & 36.53 \\
\hline
\end{tabular}




\begin{tabular}{llllll}
\hline Transportation & 233.67 & 243.46 & 0 & 740 & 11.26 \\
Water & 73.33 & 75.52 & 0 & 400 & 3.53 \\
Sacks/bags & 307.0 & 283.61 & 0 & 1100 & 14.79 \\
Total Variable costs & 1688.33 & 1232.81 & 0 & 4500 & 81.32 \\
Fixed cost & & & & & \\
Depreciation of equ & 387.80 & 408.009 & 0 & 1350 & 18.68 \\
Total cost & $2,076.1$ & 1512.45 & 0 & 49500 & \\
Gross Margin & 3604.7 & 5865.16 & -3360 & 26,000 & \\
Net profit & 3216.9 & 5683.97 & -3560 & 25,200 & \\
Rate of Return & 1.5494 & 2.13 & -1.0 & 8.33 & \\
Operating Cost ratio & 0.31897 & 0.30 & 0 & 1.34 & \\
Benefit-Cost ratio & 2.5495 & 2.19 & 0 & 9.33 & \\
\hline
\end{tabular}

Note: $\$ 1=\$ 370$ as at the time of the survey

Source: Field Survey, 2016

\section{Profitability Test}

The result of profitability test is presented in Table 4. The test employed independent sample t-test to ascertain whether there will be significant difference in the Total Costs (TC) and revenues of processors of different cassava products. The number of processors in each case differs. The results show that there was significant difference $(\mathrm{t}=9.73 ; 5.46 ; 3.82 \mathrm{p} \leq 0.01)$ between the total costs and revenues in cassava processing into garri, chips and fufu/akpu This implies that cassava processing into garri, chips and fufu/akpu are profitable. This is in line with the findings of Lawal et al. [21] and Ehinmowo et al. [27] who found that cassava processing to garri, flour/lafun and akpu are profitable.

Table 3: Profitability Test result showing the difference between Total Cost and Revenue in cassava processing

\begin{tabular}{|c|c|c|c|c|c|c|c|c|}
\hline $\begin{array}{l}\text { Cassava } \\
\text { products }\end{array}$ & $\begin{array}{l}\text { Group } \\
\text { Variables }\end{array}$ & $\begin{array}{l}\text { Mean } \\
\text { (N) }\end{array}$ & $\begin{array}{l}\text { Standard } \\
\text { Dev }\end{array}$ & $\begin{array}{l}\text { Mean } \\
\text { Diff }\end{array}$ & t- Value & Df & $\begin{array}{l}\text { Sign (2- } \\
\text { tailed) }\end{array}$ & n \\
\hline Garri & $\begin{array}{l}\text { Revenue } \\
\text { Total Cost }\end{array}$ & $\begin{array}{l}10,616 \\
3,566.8\end{array}$ & $\begin{array}{l}5446.39 \\
1353.24\end{array}$ & 7049.22 & $9.730 * * *$ & 118 & 0.000 & 48 \\
\hline Fufu/Akpu & $\begin{array}{l}\text { Revenue } \\
\text { Total Cost }\end{array}$ & $\begin{array}{l}5,293.0 \\
2,076.1\end{array}$ & $\begin{array}{l}6346.46 \\
1512.46\end{array}$ & 3216.87 & $3.82 * * *$ & 118 & 0.000 & 29 \\
\hline Chips & $\begin{array}{l}\text { Revenue } \\
\text { Total cost }\end{array}$ & $\begin{array}{l}5,297.9 \\
2,459.8\end{array}$ & $\begin{array}{l}3704.98 \\
1571.54\end{array}$ & 2838.100 & $5.46 * * *$ & 118 & 0.000 & 15 \\
\hline
\end{tabular}

Note: $\$ 1=\$ 370$ as at the time of the survey, $n=$ number of processors

*** Significant at $1 \%$

\section{Result of ANOVA Showing the Difference in net Profit among Cassava Products}

Table 5 presents the result of Analysis of Variance (ANOVA) showing the difference in net profits of different cassava products. The result shows that there was a significant difference $(\mathrm{F}=14.92 ; \mathrm{P} \leq 0.01)$ in the profit levels of garri, chips and fufu/akpu. This means that net profits derived from processing cassava into garri, chips and fufu/akpu vary significantly. Moreover, the result of the post-hoc of ANOVA (Table 6) shows that garri's profit is significantly higher than both chips and fufu/akpu. However, between chips and fufu/akpu, fufu/akpu's profit is higher than that of chips although the difference is not significant. In other words, among the three cassava products studied, garri had the highest profit while chips had the least profit. 
Table 4: Result of ANOVA showing the difference in net profits among cassava products

\begin{tabular}{llclll}
\hline Garri/chips/akpu & Sum of squares & Degree of freedom & Mean square & F & Sig \\
\hline Between groups & 651300000 & 2 & 325600000 & $14.916^{* * *}$ & 0.000 \\
Within groups & 3864000000 & 177 & 21830000 & & \\
Total & 4515000000 & 179 & & & \\
\hline
\end{tabular}

Table 5: Result of Post-Hoc ANOVA showing the difference in net profits among products

\begin{tabular}{lllcr}
\hline Products & & Mean diff & Standard error & Sign \\
\hline Garri & & & & \\
& Chips & $4211.117^{*}$ & 853.0 & 0.000 \\
Fufu/Akpu & $832.35^{*}$ & 853.0 & 0.000 \\
& & & & \\
& Garri & $-4211.117^{*}$ & 853.0 & 0.000 \\
Fufu/Akpu & Fufu/Akpu & -378.767 & 853.0 & 0.658 \\
& & & & 0.000 \\
& Garri & $-3832.35^{*}$ & 853.0 & 0.658 \\
\hline
\end{tabular}

*. The mean difference is significant at the 0.05 level.

Source: Field Survey, 2016

\section{Constraints to Cassava Processing}

The major constraints to cassava processing are presented in Table 6. The result shows that $70 \%$ of the respondents had transportation problem; absence of good road resulted in high cost of transportation and this affected proper distribution of the raw materials in the study area. Majority (76.7\%) of the respondent reported labour scarcity. More so, $76.7 \%$ of the respondents reported poor road respectively. Scarcity of water supply was reported by $70 \%$ of the respondents.

Another major obstacle to cassava processing in the study area is poor equipment $(80 \%)$. Grating and milling machines were owned by very few in the study area. In a community of about 600 farm families, only three (3) families own and operate the machine as business ventures. This resulted to long queues thereby causing delay in processing. Inadequate capital was also mentioned by most respondents (90\%). This problem was as a result of farmers limited access to loan from financial institutions. Again, $100 \%$ of the cassava processors reported unpredictable climate as a constraint in processing, in the case of sun-drying of chips especially in the raining season.

Table 6: Constraints to Cassava Processing

\begin{tabular}{clll}
\hline S/No & Constraints & Frequency & Percent \\
\hline 1. & Unpredictable Climate & 60 & 100.0 \\
2. & Inadequate Capital & 54 & 90.0 \\
3. & Poor Equipment & 48 & 80.0 \\
4. & Labour Scarcity & 46 & 76.7 \\
5. & Poor Road & 46 & 76.7 \\
6. & Poor Water Supply & 42 & 70.0 \\
7. & High Cost of Transportation & 42 & 70.0 \\
\hline
\end{tabular}

Multiple responses recorded. Source: Field Survey, 2016

\section{Discussion}

\section{Forms of Cassava Processing and Technology used in Processing}

The result shows that majority of the respondents use traditional method. This implies that modern processing technologies are highly non-existent. In cassava processing to garri, cassava roots are traditionally grated into a mash or pulp as part of the process to remove cyanide and make 
the roots safe to eat. Traditional cassava graters are usually made from perforated metal sheets. These rust quickly and are difficult to keep clean. Moreover, they are also very slow and labourintensive to use. Cassava processing in the study area is still rudimentary which is time consuming and energy sapping. In cassava processing to garri, the traditional method was adopted during peeling, washing, sieving and frying while the improved method are only employed at grating and jacking stages. However, in processing to chips and fufu/akpu, all the processes were done manually or traditionally with no improved technology. This supports the findings of Omolara et al. [22], Bamidele [29]; and Oladejo et al. [28] who found that processors of lafun and Pupuru/flour respectively, made use of local method of processing but contrasts the findings of Ashaye [30] who observed the use of semi-modern method of processing. The study also found that most respondents process cassava into garri and Fufu/akpu. Garri processing was high due to easily available rudimentary tools, ready market and inherent high profit. The efficiency of the processing process could be enhanced through the use of highly modernized equipment which will ensure timely performance and improved output. As a consequence of the above constraint, processors limit their processing to mainly garri and fufu/akpu that require simple rudimentary tools. It was observed that none of the processors process cassava into chips only in the study area as a result of the absence of mechanized dryer as it can only be processed in dry season when there can be adequate sun. The processing of cassava mainly into garri as obtained in this study is consistent with the findings of Muhammad-Lawal et al. [20], Ehinmowo et al. [27] and Okeowo [31] and who found majority of the processors (49 percent) processed cassava into garri.

\section{Costs and Returns in Cassava Processing}

The variable costs involved in cassava processing into garri, chips and akpu are numerous but specific to each processing enterprise. While the mean revenue in each case far exceeds the mean total variable costs; it follows that the processing exercise gives incentives to the processors in form of profit and this has ensured the sustainability of the business in the area. In the processing of cassava into garri, the major constituents of costs include cost of tubers, firewood and labour. Bags, water and transportation exerts minimal costs in garri processing. Palm oil was occasionally added to improve quality and enhance the nutritional value. The benefit-cost ratio was 2.976 which depicts that cassava processing into garri is highly profitable and viable. This is consistent with the findings of Muhammad-Lawal et al. [20] who found that garri gave the highest Gross Margin among four cassava products.

Similarly, the major cost elements apart from cassava tubers include labour, water and transport in cassava processing into chips. Labour costs include cost of peeling, washing and sundrying. However, the mean gross margin for chips was approximately less than half of garri while the mean total variable cost was less than that of garri. The price of chips was $\$ 57.50 / \mathrm{kg}$. However, the mean gross margin of chips was about one-third of garri. The benefit-cost ratio was 2.15; thus, cassava processing into chips is considered viable and profitable.

Furthermore, the mean revenue from fufu/akpu was the least when compared to garri and chips. However, its gross margin was higher than chips but less than garri. This implies that its mean total variable cost was the least. However, the major components of cost in fufu/akpu processing are labour, cassava tuber, sacks/bags and transportation. Labour costs include cost of peeling, washing, sieving, draining of water and bagging. The rate of return on investment to fufu processing estimated at $155 \%$ indicates that fufu processing is a profitable enterprise in the study area. A comparison of the returns to cassava processing revealed that garri had the highest gross margin which was about $213.51 \%$ of the total variable cost. A similar result was obtained by Okorie et al. [32] where garri gave the highest value-added to cassava processing in Imo State and Ehinmowo et al. [27] who found Benefit-Cost-Ratio (BCR) for garri processing in Ondo as 2.24, Oyo as 1.75 and Ogun as 1.85 , emphasizing the profitability of the business.

\section{Profitability Test}

When the total variable costs and revenue in cassava processing into the various products were compared, there was a significant difference between them. This means that the difference between revenue and total variable costs was not by chance; hence processing of cassava into garri, 
chips and fufu/akpu were profitable. This result corroborates previous reports that in Nigeria and other African countries processing of cassava into garri [21, 33, 27], fufu [21, 27], dried fufu [34] and lafun [21, 27], were profitable.

\section{Result of Analysis of Variance (ANOVA)}

Moreover, the result of the post-hoc of ANOVA (Table 5) shows that garri's net profit was significantly higher than both chips and fufu/akpu. This contrasts the findings of Okeowo [31] who found that $f u f u$ had the highest margin in Epe LGA, Lagos State Nigeria, although other products such as garri and chips were equally profitable. However, between chips and fufu/akpu, fufu/akpu's profit is higher than that of chips although the difference was not significant. In other words, among the three cassava products studied, garri had the highest net profit while chips had the least net profit. This could be attributed to the ease of processing and the ready market for the products: as garri had the highest demand in the locality compared to fufu/akpu and chips.

\section{Constraints to cassava processing}

The major constraints as outlined by the respondents include inadequate capital, poor equipment, poor road, labour scarcity and inadequate water supply. Absence of good roads was a major limiting factor as majority of the roads are not motorable and hence do not encourage largescale processing. Again, the bad roads lead to high transportation bills which further decimate the profit. Furthermore, water scarcity and labour were other problems. There is scarcity of water especially during dry season when streams and wells dry up. This makes getting water a serious problem for the processors. Again, there is always scarcity of labour especially during season as most operations are done manually.

Another major constraint is poor equipment. This resulted to long queues which were regular at grating and jacking stages thereby causing delay in processing. This is caused by the near absence or few machines in the community. This is in line with Omolara et al. [22] who found that $81.5 \%$ of women processors in Osun State were faced with equipment problem. Processors complained about inadequate capital. This problem was as a result of farmers limited access to loan from financial institutions. This is consistent with the result found by Omolara et al. [22], Muhammad-Lawal et al. [20], Oladejo et al., [28] and Ehinmowo et al. [27].

\section{Conclusions and Recommendations}

Processing of cassava into garri, cassava chips and fufu/akpu are still being carried out using traditional technologies. Cassava processing is a viable and profitable enterprise that will boast food production vis-à-vis reduce the syndrome of poverty in the study area, if properly managed. It is also one of the enterprises that has potential of adding value to our Gross Domestic Product (GDP) and as well create employment opportunities for the teeming population. High sales/turnover is the key to profitability; hence market development is the key driver of the profitability we desire in the Nigerian cassava industry.

Efforts should be made by technology developers in making modern processing technologies and devices to ease the processing process. There should be capacity building for the processors to improve their social and wellbeing for optimal output The government should as a matter of urgency provide adequate infrastructure such as storage facilities and good road network to solve the present problems of processors in the area. Soft loans or grants should be advanced to processors in order to increase their capital base.

\section{Conflict of Interest}

There is no conflict of interest.

\section{Acknowledgements}

Our profound appreciation goes to Mr. Olaide Akande for his tutorage and mentoring. 


\section{References}

[1] A.P. Ugwaja., O.B. Aledesote, Effects of socio-economic characteristics of cassava based farmers on their adoption of climate change Adaptation strategies in Emohua Local Government Area of Rivers State. Proceedings of the Nigeria Association of Agricultural Economics held at the Federal University of Technology Akure, Nigeria. 24th-27th, February, Pp. 196-202, (2014).

[2] A.I. Bamgboye, B. S. Kosemani, Energy Input in the Production of Cassava, Energy and Environment Research. 5(1) (2015) 42-48.

[3] L. Shubo et al., The industrial application of cassava: current status, opportunities and prospects, Journal of the Science of Food and Agriculture. 97 (2017) 2282-2290.

[4] A.O. Omotayo, A.J. Oladejo, Profitability of Cassava-based Production Systems, J. Hum. Ecol. 56(1, 2) (2016) 196-203.

[5] S.O. Odebode, Appropriate Technology for Cassava Processing in Nigeria: User's Point of View, Journal of International Women's Studies. 9(3) (2008) 269-286.

[6] A.G. Iyagba, A review on Root and Tuber Crop Production and their weed management among small scale farmers in Nigeria, APRN Journal of Agricultural and Biological Science. 5(4) (2010) 52-58.

[7] I. Abdul-Azeez, Cassava Export and Local Utilization in Nigeria Top Secrets. The Consulting, Thursday May 30th, 2013 (2013).

[8] F.I. Nweke, Spread and Performance of Cassava Varieties in Nigeria COSCA (1988). Working paper No. 15 Collaborative Study of Cassava in Africa. IITA Ibadan, Nigeria.

[9] A.O. Ubalua, E.N.A. Mbanaso, A Novelgene, Transformation Technique for Farmer's Preferred Cassava Cultivar (Nwibibi) from Nigeria, World Journal of Agricultural Sciences. 9(3) (2013) 284-289.

[10] FAO "Nigeria at a glance". Food and Agriculture Organisation of the United Nations. (2017) Available at http://www.fao.org/nigeria/fao-in-nigeria/nigeria-at-a-glance/en/, accessed 1 September 2017.

[11] A.K.O. Nnadozie et al., Nigerian Cassava Potentials in National Economic Development, Science Journal of Business and Management. 3(5-1) (2015) 47-49.

[12] FAO (Food and Agriculture Organization of the United Nations) (2013). FAOSTAT Online Statistical Database. Accessed on 01/07/2013. http://faostat.fao.org.

[13] USAID New partners invest in Mozambique's Future. Washington, D.C.: USAID (2015).

[14] L. S. Sanusi, Industrial Agricultural Raw Materials: Critical Issues in Processing, Marketing and Investment, in: H.D. Ibrahim, B.O. Olugbemi, O.J.Marinho (Eds.), Re-engineering Raw Materials Resources: A Panacea for Economic and Industrial Development. 3RD Raw Materials Research and Development Council Annual International Conference on Natural Resources Development and Utilization. pp. 90-95. Raw Materials Research and Development Council (RMRDC), Federal Ministry of Science and Technology, Abuja, Nigeria (2012).

[15] O.O. Kuye, O.I. Ettah, Contributions of urban mixed cropping to household food Security in Nigeria and around the globe, International Journal of Environment, Agriculture and Biotechnology. 1(2) (2016) 89-101.

[16] Nigerian Institute of Social and Economic Research (NISER), Reducing Food Crop Losses through Post-Harvest Management in Nigeria, NISER Unpublished Research Study, 2013. NISER, Ibadan (2013).

[17] A. S. Olomola, Background paper for the competitive commercial agriculture in Africa study (CCAA): Nigeria case study, Nigerian Institute of Social and Economic Research, Ibadan, 2007. 
[18] P.K. Oladele, L.A. Agebetoge, A.S. Ogunlowo, Evaluation of Cassava Mash Dewatering Methods, Journal of Bioinformatics and sequence Analysis. 3(2) (2011) 23-30.

[19] I.A. Ayinde, C. A. Afolami, A. B. Aromolaran, Intra-zonal Poverty Situation among Farmers in Ogun State, Moore Journal of Agricultural Research. 3(2) (2003) 306-312.

[20] A. Muhammad-Lawal, O.A. Omotesho, F.A. Oyedemi, An Assessment of the Economics of Cassava Processing in Kwara State, Nigeria. International Conference of the African Association of Agricultural Economists, September 22-25, 2013, Hammamet, Tunisia (2013).

[21] A. M. Lawal, O. A. Omotesho, F. A. Oyedemi, An Assessment of the Economics of Cassava Processing in Kwara State, Nigeria, in: 4th International Conference of the African Association of Agricultural Economists, September 22-25, Hammamet, Tunisia, 2013.

[22] G. M. Omolara, A.A. Alabi, A. O. Omotayo, Cost and Return Analysis of Cassava Flour (Lafun) Production among the Women of Osun State, Nigeria, Science Research. 5(5) (2017) 72-77.

[23] Benue State Agricultural and Rural Development Authority (BNARDA), Implementation, Completion Report on National Special programme for Food Security NSPFS, Benue State, Nigeria pp1-23 (2005).

[24] P.I. Ater, J.C. Umeh, Spatial benefit cost analysis in the World Bank assisted fadama enterprises in Benue State. Proceeding of the 38th Annual Conference of the Agricultural Society of Nigeria (ASN). College of Agriculture, Lafia (2004).

[25] A. Zwald et al., Economic Costs and Labor Efficiencies Associated with Raising Dairy Herd Replacements on Wisconsin Dairy Farms and Custom Heifer Raising Operations. Madison: University of Wisconsin- Extension. Retrieved from http://www.uwex.edu/ces/ heifermgmt/documents/ ICPAfinalreport.pdf (2007).

[26] IRRI, Basic Procedures for Agroeconomic Research. Manila: IRRI (1991).

[27] O.O. Ehinmowo, J.A. Afolabi, A.I. Fatuase, Determinants of Profitability among Small-Scale Cassava Processors in South Western Nigeria, RJOAS. 1(37) (2015).

[28] J.A. Oladejo et al., Profitability of Cassava Processing (Pupuru Flour) in Ondo State, Nigeria, Ge-International Journal of Management Research. 2(10) (2014).

[29] A. A. Bamidele, Economics of Cassava Flour Production in Odeda Local Government Area, Ogun State, Nigeria. (2007).

[30] O. A. Ashaye, T. A. Adegbulugbe, O. J. Dawodu, Evaluation of the Processing Technologies of Cassava Chips and Flour in Oyo and Ogun States of Nigeria, World Journal of Agricultural Sciences. 1(1) (2005)56-58.

[31] T. A. Okeowo, Profitability of Cassava Processing in Epe Local Government Area of Lagos State, International Journal of Applied Research and Technology. 4(9) (2015) 39-47.

[32] O. C. Okorie, D.O. Ohajianja, N.C. Ehrim, Value Chain Analysis of Cassava and Cassavabased Products in Imo State, Nigeria, International Journal of Natural and Applied Sciences. 2(4) (2006).

[33] J.O. Effiong et al., Costs and Returns Analysis of Gari Processing in Owerri West Local Government Area of Imo State, Nigeria, Journal of Chemical, Biological and Physical Sciences. 4(2) (2014) 1646-1653.

[34] I. A. Ayinde et al., Cost-Benefit Analysis of the Processing of a Shelf Stable Cassava Fufu in Nigeria, in: Proceedings of the Sixth International Scientific Meeting of the Cassava Biotechnology Network, held at International Centre for Tropical Agriculture, Cali, Columbia (2004). 